\title{
Clinico- Epidemiological profile of assault cases at a tertiary centre in Indore
}

\author{
Jitendra Singh Tomar ${ }^{1}$, Sunil Soni ${ }^{2 *}$, B.K. Singh ${ }^{3}$, Rahul Agrawal $^{4}$ \\ ${ }^{1,2}$ Assistant Professor, ${ }^{3}$ Associate Professor, ${ }^{4}$ Post Graduate Resident, ${ }^{1-4}$ Dept. of Forensic Medicine, Mahatma Gandhi Memorial Medical \\ College, Indore, Madhya Pradesh, India
}

*Corresponding Author: Sunil Soni

Email: drjitendrasinghtomar@gmail.com

\begin{abstract}
Assault cases coming to casualty of a hospital primarily reflects the intensity of the crime of that region. The present study was conducted in the casualty of Sri Aurobindo Medical College and Post Graduate Institute, Indore. Duration of study was 2 years from 1 July 2015 to 30 June 2017 during which 194 cases were studied. Out of all the cases male victims were 163(84.02\%) and females were 31(15.98\%). Adult age group from 21- 30 years was most commonly affected with a sum total of 72(37.11\%) victims. Commonest injury was laceration in 76(32.07\%) cases followed by swelling in 55(23.20\%) cases present over different parts of body. Surgery department was called for intervention in $133(68.56 \%)$ of cases than orthopedics department in $71(36.60 \%)$ cases. All the victims were examined meticulously, treated and injury report was made and further informed to police for investigation and judicial proceedings.
\end{abstract}

Keywords: Assault, Injuries, Casualty, Medicolegal.

\section{Introduction}

According to Section 351 of the IPC 'assault' is defined as "every attack or threat or attempt to apply force on the body of another in a hostile manner". . Casualty department of any healthcare centre deals with assault cases. Victims comes by self or is being brought by other persons to casualty, where it is duty of casualty medical officer primarily to treat the patient and after stabilizing the patient to prepare an injury report, noting down all the injuries along with a short history of incidence, size, site and duration of the injuries inflicted.

\section{Material and Methods}

This is a retrospective study of assault cases registered in medico-legal register in casualty of Sri Aurobindo Medical College, Indore from $1^{\text {st }}$ July 2015 to $30^{\text {th }}$ June 2017 for a period of 2 years. During this study period a total of 194 assault cases were registered in the casualty. The collected data was analyzed and presented in tables, graphs and pie charts by using various parameters and compared with other studies.

\section{Observations and Results}

In this two year retrospective study, a total number of 194 medico-legal cases were reported and studied. Out of total cases male predominance was noted with $84.02 \%$ of cases (Fig. 1). Maximum patients coming to casualty were from the age group of 21-30 years i.e. $37.11 \%$ followed by $27.32 \%$ cases from 31-40 years age group, whereas least number of patients were from age group of 1-10 years i.e. $1.03 \%$ (Table 1 ). While the majority of male $(46.3 \%)$ were from 21-30 years age group and female (6.18\%) victims were from 31-40 years age group.

Taking religion into consideration majority of the patients belonged to Hindu religion i.e. 187(96.39\%), patients from Muslim community were $6(3.09 \%)$ and remaining $1(0.51 \%)$ was from Christian community (Fig. no.2). Most of the patients coming to the casualty were from urban areas accounting to be $127(65.46 \%)$ and remaining $67(34.54 \%)$ patients came from rural areas. (Fig. 3)

Total 237 different injuries were noted to have caused all over victim's body, maximum 76(32.07\%) injuries were lacerations followed by swelling in 55(23.20\%) cases. Contusions and incised wound accounted for 28(11.81\%) and $25(10.55 \%)$ respectively. Gunshot injury, injury by flame, broken tooth and amputation of penis were seen in only one cases each. (Table 2)

Surgery department was called for intervention in $133(68.56 \%)$ of cases than orthopedics department in $71(36.60 \%)$ cases and other departments were also referred as shown in (Table 3).

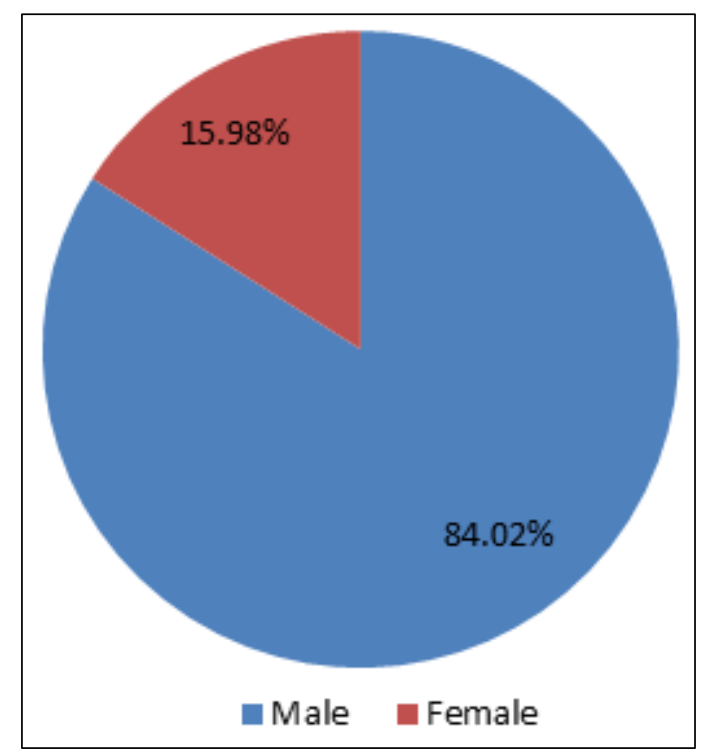

Fig. 1: Genderwise distribution 


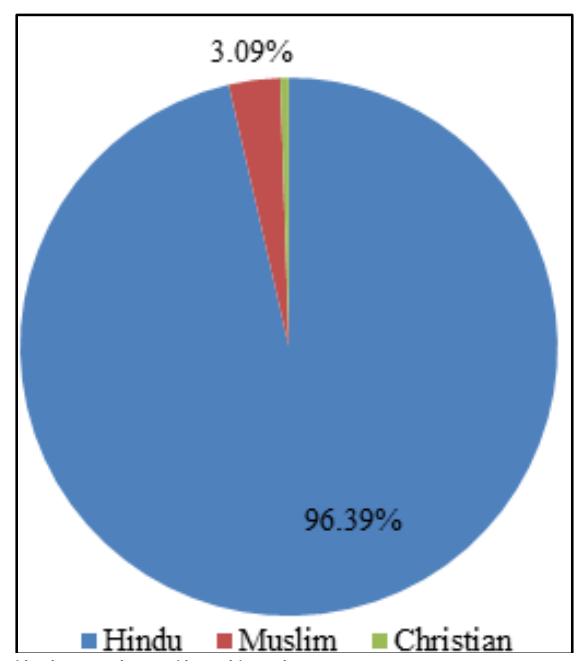

Fig. 2: Religionwise distribution.

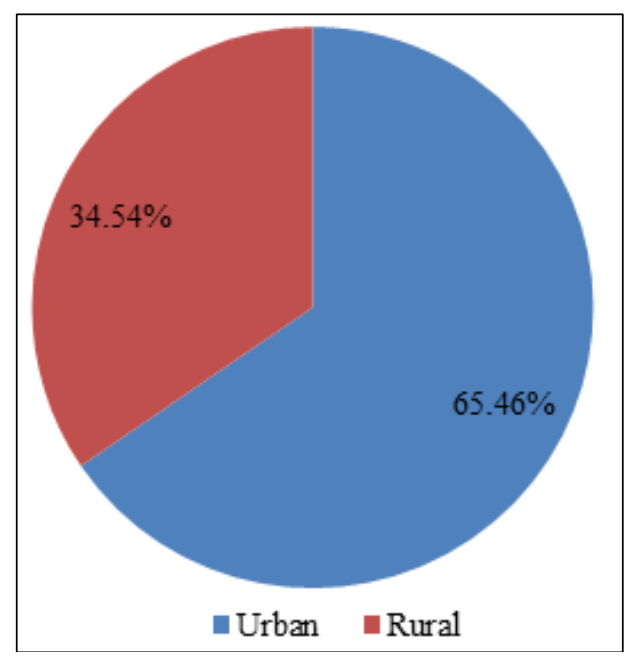

Fig. 3: Region wise distribution

Table 1: Age and sexwise distribution

\begin{tabular}{|c|c|c|c|}
\hline Age group & Male & Female & Total \\
\hline $0-10$ & $2(1.03 \%)$ & $0(0 \%)$ & $2(1.03 \%)$ \\
\hline $11-20$ & $27(13.92 \%)$ & $1(0.51 \%)$ & $28(14.43 \%)$ \\
\hline $21-30$ & $62(31.96 \%)$ & $10(5.15 \%)$ & $72(37.11 \%)$ \\
\hline $31-40$ & $41(21.13 \%)$ & $12(6.18 \%)$ & $53(27.32 \%)$ \\
\hline $41-50$ & $22(11.34 \%)$ & $5(2.58 \%)$ & $27(13.92 \%)$ \\
\hline$>50$ & $9(4.64 \%)$ & $3(1.54 \%)$ & $12(6.18 \%)$ \\
\hline Total & $163(84.02 \%)$ & $31(15.98 \%)$ & $194(100 \%)$ \\
\hline
\end{tabular}

Table 2: Types of injuries

\begin{tabular}{|c|c|c|}
\hline Type & Frequency & Percentage \\
\hline Abrasion & 26 & $10.97 \%$ \\
\hline Swelling & 55 & $23.20 \%$ \\
\hline Stab & 9 & $3.80 \%$ \\
\hline Lacerated Wound & 76 & $32.07 \%$ \\
\hline Contusion & 28 & $11.81 \%$ \\
\hline Incised & 25 & $10.55 \%$ \\
\hline Fracture & 12 & $5.06 \%$ \\
\hline Nail marks & 1 & $0.42 \%$ \\
\hline Bite marks & 1 & $0.42 \%$ \\
\hline Broken tooth & 1 & $0.42 \%$ \\
\hline Gunshot & 1 & $0.42 \%$ \\
\hline Amputation of penis & 1 & $0.42 \%$ \\
\hline Burn & 1 & $0.42 \%$ \\
\hline
\end{tabular}

Table 3: Departmentwise distribution of cases

\begin{tabular}{|l|c|}
\hline \multicolumn{1}{|c|}{ Department } & Total (percentage) \\
\hline Surgery & $133(68.56 \%)$ \\
\hline Orthopedics & $71(36.60 \%)$ \\
\hline OMFS & $15(7.73 \%)$ \\
\hline ENT & $9(4.64 \%)$ \\
\hline Medicine & $3(1.55 \%)$ \\
\hline Obstretics and Gynaecology & $2(1.03 \%)$ \\
\hline Neurosurgery & $2(1.03 \%)$ \\
\hline Ophthalmology & $1(0.51 \%)$ \\
\hline Pediatric surgery & $1(0.51 \%)$ \\
\hline Pediatrics & $1(0.51 \%)$ \\
\hline
\end{tabular}




\section{Discussion}

During our study it was found that males outnumbered females as victims with 163 males $(84.02 \%)$ and 31 females $(15.98 \%)$. This is in comparison with the study conducted by Mittal S et al ${ }^{2}$ which showed males were $82.5 \%$ and rest were females. A study done at Mangalore by $\mathrm{Vij} \mathrm{A}$ et $\mathrm{al}^{3}$ also showed consistent findings with males forming the major case load i.e. $79.77 \%$. Similar male predominance was observed in other studies by Malik Y et al. ${ }^{4}$ This is because males are more involved in outdoor activities and are more aggressive in compared to females involved in fights, so this makes them more vulnerable to any injury.

Our study showed that the most commonly affected age group was 21-30 years (37.11\%) while the least commonly affected age groups were $0-10$ years with $1.02 \%$ cases. A study done by Bhullar DS and Aggarwal KK ${ }^{5}$ showed that most commonly affected age group was 21-40 years in 58\% cases. Studies done by Mittal $\mathrm{S}$ et $\mathrm{al}^{2}$ and Garg V and Verma S.K. ${ }^{6}$ also showed that maximum number of victims belonged to the age group 21-30 years age group and the least affected were those in the $0-10$ years age group.

This study found that the urban population was mainly affected with $127(65.46 \%)$ victims. This is in contrast with the studies by Mittal S et al and Oberoi SS et al which showed the rural population was mainly affected. ${ }^{2,7}$ this may be because of the reason that our medical college serves urban population.

In our study maximum $76(32.07 \%)$ injuries were lacerations followed by swelling in 55(23.20\%) cases. Contusions and incised wound accounted for $28(11.81 \%)$ and $25(10.55 \%)$ respectively. Similar findings with lacerations most commonly noted 646(32.28\%) was seen in study done by Thube HR et $\mathrm{al}^{8}$ and Howe et $\mathrm{al}^{10}$ having most common injuries as laceration in $21 \%$ cases. However these findings were inconsistent with study done by Fothergill et $\mathrm{al}^{9}$ having major injuries were contusions in $53 \%$ of cases.

In our study Surgery department was called for intervention in $133(68.56 \%)$ of cases followed by orthopedics department in $71(36.60 \%)$ cases. This observation is concurrent with the study done by Timsinha $\mathrm{S}$ et $\mathrm{al}^{11}$ who studied all medicolegal cases in casualty and found involvement of department of surgery in 58.80\% cases followed by orthopedics department in $16.69 \%$ cases.

\section{Conclusion}

It was also found that males were the victims in a majority of cases belonged to the younger age group i.e. 21-30 years from urban population. Lacerations were the most common injury observed which implicates use of blunt weapons. In the present society various discrepancies, maladjustments, disharmony etc. are responsible for constant rise in the crime. Effective policing, well aware and educated society can be among various tools to cope up with current scenario. Similar studies over different periods of time will help in providing a background for an effective, multifaceted crime control policy.

\section{Conflict of Interest: None.}

\section{References}

1. Malik M.R. Criminal Manual, Indian Penal Code (45 of 1860), Professional book publishers, 2011:168-72.

2. Mittal S, Chanana A, Rai H, Dalal JS. Medicolegal study of mechanical injuries in culpable homicide (excluding deaths due to rash and negligent act). $J$ Ind Acad Forensic Med 2005;27(4):226-30.

3. Vij A, Menon A, Menezes RG, Kanchan T, Rastogi P. A retrospective review of homicides in Mangalore, South India. $J$ Forensic Leg Med 2010;17:312-5

4. Malik Y, Chawla R, Sharma G, Malik P, Singh R, Tripati A. Profile of Medico-legal cases in casualty of a Rural Medical College of Haryana. J Indian Academy Forensic Med 2013;35(4):367.

5. Bhullar DS, Aggarwal KK. Medico Legal Diagnosis \& Pattern of injuries with sharp weapons. J Ind Acad Forensic Med 2007;29(4):112-4.

6. Garg V, Verma S.K. Profile of Medico-legal Cases at Adesh Institute of Medical Sciences and Research, Bathinda, Punjab. JIAFM 2010;32(2):150-2.

7. Oberoi SS, Agrawal KK, Bhullar DS, Agrawal AD, Walia DS, Singh SP et al. Profile of Assault Cases in Patiala. J Punjab Acad Forensic Med Toxicol 2012;12(1):17-21

8. Thube HR, Chikhalkar BG, Nanandkar SD. A Prospective Study of Injury Pattern in Victim of Assault Attended in South Mumbai Government Hospital. J Indian Acad Forensic Med 2015;37(1):37-40

9. Fothergill N, Hashemi K. A prospective study of assault victims attending a suburban A\&E Department., Arch Emerg Med 1990;7:172-7.

10. Howe A, Crilly M. Violence in the community, Soc Public Health 2002;116 (1):15-21.

11. Timsinha S, Manjari Kar S, Baral MP, Ranjitkar M. Profile of Pattern of Medico-Legal Cases in the Casualty of A Teaching Hospital of Western Region of Nepal. J Indian Acad Forensic Med 2015;37(1):46-9.

How to cite this article: Tomar JS, Soni S, Singh BK, Agrawal R. Clinico- Epidemiological profile of assault cases at a tertiary centre in Indore. Int J Forensic Med Toxicol Sci 2019;4(2):39-41. 